See discussions, stats, and author profiles for this publication at: https://www.researchgate.net/publication/341079115

\title{
Empowering indigenous communities through participation in tourism
}

Article in International Journal of Tourism Anthropology · May 2020

DOI: 10.1504/IJTA.2019.107323

\section{CITATIONS}

0

8 authors, including:

Nur Aliah Mansor

University of Malaysia, Kelantan

17 PUBLICATIONS 11 CITATIONS

SEE PROFILE

Simpong derweanna

University of Malaysia, Kelantan

15 PUBLICATIONS 10 CITATIONS

SEE PROFILE

\section{READS}

36

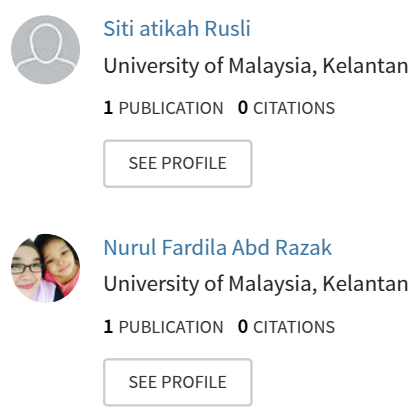

Some of the authors of this publication are also working on these related projects:

Breakfast Preparation Slide View project

Fostering Socio-Economic Activities and Community Involvement in Native Based Tourism Product among Orang Asli View project 


\title{
Empowering indigenous communities through participation in tourism
}

\section{Nur Aliah Mansor and Mazne Ibrahim}

Faculty of Hospitality, Tourism and Wellness,

Universiti Malaysia Kelantan,

Kota Bharu, 16100, Kelantan

Email: aliah.m@umk.edu.my

Email: mazne@umk.edu.my

\section{Siti ‘Atikah Rusli}

School of Hospitality,

Sunway University,

Sunway, 47500, Malaysia

Email: atikahr@sunway.edu.my

Derweanna Bah Simpong*, Nurul Fardila Abd Razak, Harnidah Samengon, Nurashikin A Ridzuan and Nur Azimah Othman

Faculty of Hospitality, Tourism and Wellness,

Universiti Malaysia Kelantan,

Kota Bharu, 16100, Kelantan

Email: derweanna@umk.edu.my

Email: fardila.ar@umk.edu.my

Email: harnidah@umk.edu.my

Email: nurashikin.ar@umk.edu.my

Email: azimah.o@umk.edu.my

${ }^{*}$ Corresponding author

\begin{abstract}
This study explores the involvement of Malaysian indigenous peoples (Orang Asli) at both the individual and community level to analyse the impact of tourism development on the economic and socio-cultural aspects of their communities. The study was conducted at two tourism sites, Bukit Tadom and Cameron Highlands. Semi-structured interviews were conducted with 14 participants from the Orang Asli community and Orang Asli employees and management at the sites. Data were thematically analysed. Orang Asli communities recognised the opportunities that tourism development brings to their social and economic conditions, although it is not wholly beneficial. They also want to be actively involved in tourism planning. The study contributes to the development of indigenous peoples, especially in Malaysia, promoting a new perspective on long-term tourism development. It also highlights several
\end{abstract}


new considerations that should be addressed by the authority in planning and managing tourism sites, especially in regard to community acceptance, involvement and demand for benefits.

Keywords: community; participation; indigenous; tourism; community participation; Orang Asli; Malaysia; rural; empowerment.

Reference to this paper should be made as follows: Mansor, N.A., Ibrahim, M., Rusli, S.A., Simpong, D.B., Razak, N.F.A., Samengon, H., Ridzuan, N.A. and Othman, N.A. (2019) 'Empowering indigenous communities through participation in tourism', Int. J. Tourism Anthropology, Vol. 7, Nos. 3/4, pp.309-329.

Biographical notes: Nur Aliah Mansor is a Lecturer in the Faculty of Hospitality, Tourism and Wellness at the Universiti Malaysia Kelantan. She received her Master's degree in Hospitality Management from Universiti Teknologi MARA in Shah Alam, Malaysia. Her interest is in collective behaviour, agency and social identity, and her main research area is East Asian studies.

Mazne Ibrahim is a Lecturer in the Faculty of Hospitality, Tourism and Wellness at Universiti Malaysia Kelantan. She earned a BSc in Hotel Management from Universiti Teknologi MARA, and a MSc in Tourism Planning from Universiti Teknologi Malaysia. To date, she has conducted research on religious tourism and the hotel business. Her research interests include hospitality and tourism innovation and product development.

Siti 'Atikah Rusli is a Lecturer in the School of Hospitality at Sunway University, Malaysia. She earned a Bachelor's degree in Food Service Management and a Master's degree in hospitality management from Universiti Teknologi MARA. She has taught subjects in the area of hospitality in both private and public universities. Her research interest is in Islamic tourism, pro-poor tourism and service quality.

Derweanna Bah Simpong is currently a Senior Lecturer and Head of the Hospitality Department at the Faculty of Hospitality, Tourism and Wellness, Universiti Malaysia Kelantan (UMK). She has been involved in several consultancy projects in indigenous tourism. Her research interests are hospitality management, gastronomy and culinary tourism, food and service management.

Nurul Fardila Abd Razak is a Hospitality Lecturer in the Faculty of Hospitality, Tourism and Wellness at Universiti Malaysia Kelantan. She earned a BSc and MSc in Food Service Management from Universiti Teknologi MARA. Her research interests include gastronomy and culinary tourism and food service management.

Harnidah Samengon is a Lecturer in the Faculty of Hospitality, Tourism and Wellness at Universiti Malaysia Kelantan. She earned a BSc in Hotel and MSc in Hospitality Management from Universiti Teknologi MARA. To date, she has conducted research on technology in hotels and hotel business management. Her research interests include hospitality innovation and technology and service recovery in the hospitality and tourism sector.

Nurashikin A Ridzuan is a Lecturer in the Faculty of Hospitality, Tourism and Wellness at Universiti Malaysia Kelantan. She earned a BSc in Hotel 
Management and Master in Hospitality Management. Both from Universiti Teknologi MARA (UiTM). To date, she has conducted research on tourism and indigenous studies. Her research interests include education and technology innovation in the hospitality and tourism industry.

Nur Azimah Othman is a Lecturer in the Faculty of Hospitality, Tourism and Wellness at Universiti Malaysia Kelantan. She received a diploma and degree in culinary arts and Master in Gastronomy from Universiti Teknologi MARA. She has been with the Garde Manger Department, Langkawi Lagoon Resort, where she was the Commis II. Her research interests include culinary arts, hospitality, and food innovation.

\section{Introduction}

Tourism can be seen as a means of empowering local communities, especially indigenous people. Political, psychological and social aspects are involved in empowering indigenous communities, resulting in the people achieving greater economic results, through trust, social cohesion and political influence in acquiring and controlling their own land (Weaver, 2010). Empowering indigenous communities includes acknowledging the community as an entity with lawful land ownership rights, and creating rules and procedures for implementing those rules (Sofield and Li, 2007). Tourism development can bring many positive economic benefits to an area through the generation of income and employment opportunities from the development of infrastructure such as sealed roads, hotels, lodges and resorts (Ghazali et al., 2006). However, there is still a long way in ensuring the benefits to indigenous people.

In Malaysia indigenous people are known collectively as Orang Asli. According to the Department of Orang Asli Development (JAKOA), the 18 subgroups represent $0.7 \%$ of the population of Peninsular Malaysia. The Orang Asli are heterogeneous and diversified in language and culture (Kamaruddin and Jusoh, 2008). However, they are relatively poor, and marginalised socio-economically and culturally. They live in areas isolated from the civilisation and modernisation commonly seen in cities.

Tourism is regarded as a feasible way to promote rural economic development, especially among Orang Asli. Rasoolimanesh et al. (2018) argued that Orang Asli involvement in tourism development benefits the local communities. Through this development process, various socio-cultural elements, including their domestic economy, household income, education, religious beliefs and cultural aspects, have changed (Simpong et al., in press).

As tourism involving indigenous communities has been steadily growing around the world, so the Orang Asli communities in Malaysia have encountered such growth (Simpong et al., in press). Indeed, the growing number of private management companies has developed rural areas in Malaysia into tourism sites. However, as with other tourism development, indigenous community involvement should be supported by standards of to ensure feasible advancement and the use of natural resources (Carr et al., 2016). According to Jaafar et al. (2017), providing additional possibilities for the local community enables people to leverage their own resources and decision making in their daily activities. However, these changes also have drawbacks, including excessive water usage and adverse effects on communities (Mtapuri and Giampiccoli, 2017). 
Therefore, further investigation into the impact on local communities of tourism development should be undertaken. Several studies on Orang Asli communities living close to tourist sites, including their economic prosperity and improved socio-economic well-being, have already been carried out (Thompson-Carr, 2013; Lemelin et al., 2013; Carr et al., 2016). Development of tourism sites should encourage not only the monetary prosperity of indigenous groups and the preservation of their social traditions, but it should also guarantee an opportunity for upgrading their society and lifestyles (Amoamo and Thompson, 2010).

Local development of tourism sites can also provide an alternative to mass tourism (Rasoolimanesh et al., 2018), although involving the local community and their perceptions of proposed changes; local communities sit at the core of rural tourism, and thus, it is necessary to understand the extent of their involvement in tourism development. Knowledge about the relationship between tourism development and the community would be beneficial, and reduce the potential for negative impact on local people. Currently, little is known about Orang Asli community involvement in tourism development in Malaysia (Simpong et al., 2016).

This study investigates the involvement of Orang Asli communities in two tourism sites in Malaysia: Bukit Tadom and Cameron Highlands. It first explores Orang Asli involvement at both the individual and community level and analyses the economic and socio-cultural impact of tourism development on Orang Asli communities. Secondly, it investigates the empowerment among local residents, especially the Orang Asli, through the development that has taken place within the selected tourism sites. The study provides empirical evidence through comparative research to provide a better understanding of Orang Asli communities.

\section{Literature review}

\subsection{Tourism and indigenous communities}

Tourism had been introduced as a platform to increase indigenous people's involvement at both regional and national levels (Knight and Cottrell, 2016). In rural indigenous areas, it is seen as a means of sustainable development (Campón-Cerro et al., 2017; Muresan et al., 2016). From the tourism perspective, its activities have different impacts on the fiscal, environmental, cultural and societal status of the destination (Chang et al., 2018).

Tourism can be steered towards improving indigenous economic welfare by developing a symbiotic relationship between tourism, indigenous peoples and natural areas (Stronza and Gordillo, 2008; Zeppel, 2006). Empirical evidence has shown that tourism-generated income promotes diversification of domestic household income and risk management (Lapeyre, 2010; Lepper and Schroenn Goebel, 2010). According to Mbaiwa and Stronza (2010), tourism has become the primary livelihood activity of member communities, replacing various traditional and cultural activities that adversely affected the environment (e.g., hunting, gathering, livestock, crop farming). The income from tourism activities has helped to improve indigenous communities' welfare such as improving the water supply and providing homes for many families residing within indigenous communities (Mbaiwa and Stronza, 2010).

Tourism delivers many advantages to the local society, for example, taking care of the eco-system, developing the country's economy by providing foreign exchange 
earnings that enhance the living standards of local people, considering regional development, reducing waste and minimising the negative impacts to the environment.

Nevertheless, tourism can still have a negative impact on society when it is poorly organised, including negative cultural changes, severe environmental degradation and reduced welfare of individuals or local communities (Matthews, 2002). Here, several studies have suggested that inequality may be characterised by distribution of the benefits from tourism among different stakeholders involved in tourism development (Bookbinder et al., 1998; He et al., 2008). This is especially true in developing countries, in which strong economic opportunities encourage the rapid growth of tourism with little restriction. Powerful economic opportunities pose a threat if they offer big rewards, and developing countries frequently turn land ownership over to public, private and international developers by legal or illegal means (Duffy, 2000; Griffin, 2002). Despite the rapid development of tourism, indigenous peoples have received little benefit.

In fact, the involvement of local indigenous communities in tourism activities in Malaysia has been minimal. This was supported in a study by Lim and Woon (2006), who found that only a small number of Orang Asli communities had been engaged in the tourism industry, mostly working as unskilled labour in hotels, waiters in restaurants, salespersons selling souvenirs and performing other odd jobs. By playing a more active role, local communities could contribute positively to the development of tourism, given their excellent knowledge of the tropical forests, flora and fauna; their understanding of forest resources over generations can be shared with both local and international tourists.

Even though tourism activities can serve as tools to develop and fulfil the needs of indigenous communities, more substantial economic and political changes are needed, especially in the role of government and non-governmental organisations (NGOs) (Sofield and Li, 2007; Zeppel, 2006). A clear legal definition of land ownership and management of indigenous communities by the government authorities is needed to protect indigenous communities, their homes and conservation of the areas.

\subsection{The socio-cultural and economic impact of tourism development}

Sustainable tourism activities are an appropriate economic activity for indigenous communities as they are in accordance with the traditional socio-cultural and environmental practices and protection of their land (Whitford and Ruhanen, 2016). The interaction between local communities and tourists has both positive and negative effects for the economic, cultural and societal status of the destination (Chang et al., 2018).

In Malaysia, the effect of Orang Asli involvement in tourism development is apparent in both Cameron Highlands and Bukit Tadom since both sites are known as popular Orang Asli settlements. According to Fletcher et al. (2016), Orang Asli in Bukit Tadom have gained many benefits in terms of employment activities provided by tourism development. This is also the case for Cameron Highlands' Orang Asli, whose social income is believed to have increased through the number of tourist visits to their locales (Mohd Ariffin and Mohd Irwan Yen, 2017).

A number of scholars have discussed the impact of tourism on surrounding areas, and whether it is beneficial or undesirable (Peters et al., 2018). Numerous studies have discussed the relationship between economic and socio-cultural impacts in hosting communities, and centring on the effects on income and employment (Peters et al., 2018; Chang et al., 2018). The Orang Asli are no exception; the effects have resulted in the transformation of their socio-economic standards. 
According to Latip et al. (2018), tourism has positive impacts on indigenous communities, including poverty reduction. In the context of indigenous participation in the tourism industry, the impact is of mutual benefit, creating desirable tourism experiences for international markets (Rasoolimanesh and Jaafar, 2016; Latip et al., 2018). However, as much as tourism development's impact has been widely investigated, the literature suggests that its impact depends on local conditions. According to Lapeyre (2010), rapid development has brought fewer benefits to indigenous communities than expected, due to poor planning and little knowledge of the readiness factors among these groups. Although changes do occur, they are at a slow pace. However, tourism development still has an impact on poverty, and the gap in education and migration among indigenous peoples.

In addition, the social, lifestyle and cultural preservation status of these indigenous communities is affected by the development of tourism (Salleh et al., 2013). Several publications have suggested that there is renewed interest in the effects of tourism, indicating the transformation of local residents' self-identity as a significant sociocultural impact (Chang et al., 2018; Mohd Ariffin and Mohd Irwan Yen, 2017; Fletcher et al., 2016). Identity transformation involves the relationship between tourists and local residents, as well as external forces (Nunkoo and Gursoy, 2012; Xue et al., 2017).

Many of these communities continue to remain as hunters and gatherers, largely dependent on the land, rivers, and forests as their main source of sustenance and survival. On the other hand, modernisation has brought about changes to some of these communities, improving their education and livelihood but at the risk of losing their traditional skills. As such, Orang Asli cultures are being taken away from the natural habitat on which they rely for their subsistence, and their villages are being encroached upon. The tourism industry must therefore find a balance between economics, the ecosystem and social equity.

\subsection{Community involvement and collaboration with government and NGOs}

A community is crucial in tourism development process (Curcija et al., 2019). Likewise, community participation aimed at bringing together various actors in solving problem and making decision at community level (Idziak et al., 2015; Xu et al., 2019). The extent of community tourism participation also depends on several factors, such as knowledge and collaboration between government and local communities (Zamil, 2011). Community involvement aims to uphold the local culture and tradition and contributes to knowledge and skill sharing, and is believed to be a mechanism for empowering people to participate actively in community development (Aref et al., 2010).

The value of community participation in tourism development only recently been recognised. Many tourism development projects are carried out by large multinational companies and have little considerations on social and economic conditions of the local communities. Many disregard local communities in the initial tourism planning. This has caused resentment among community members and unwilling to take part in the tourism activities as they excluded in the process of tourism planning (Thetsane, 2019). Their refusal can cause backlash to the long-term economic benefits of tourism. There are community members that have to give in to development even though they initially disagreed with resort development on their land (Tonnaer, 2016). Moreover, indigenous communities have lost their tourism competitiveness as a result from excessive interference of re-development by the government. 
Indeed, local communities should be included in tourism planning and management (Alshboul, 2016). A study conducted on indigenous people carried out in the Chatham Islands experienced no spending among the tourists. Indigenous people wanted tourist that are young and enthusiastic who would be willing to spend their money (Cardow and Wiltshier, 2010). However, researchers have found that few indigenous people refuse to adapt and accept tourists has resulted to less spending. Therefore, it is necessary for indigenous community to engage in tourism activities in order to achieve healthy tourism growth.

Hence, to ensure the success of tourism development, Alshboul (2016) suggested that government collaboration with NGOs and stakeholders is necessary for sustained growth of the sectors. According to Bramwell (2011), cooperation between tourism stakeholders is a topic of growing interest among researchers and managers as it is a key aspect of public administration and tourism policy making. Bordas Rubies (2001) highlighted the benefits of NGO and government involvement in tourism development as contributing to improvement of the social and economic conditions of the tourism destinations. However, past studies (Dola and Mijan, 2006; Eshliki and Kaboudi, 2012) have argued that local community participation in tourism activities is low in developing countries. Saarinen and Lenao (2014) have highlighted the negative aspects of collaboration, including quality and cost disputes.

A study was carried out in the village of Andavadoaka, Madagascar, where the village has experienced a rapidly expanding tourism sector run by foreigners. The relative boom of the village as an emerging local commercial and societal centre was further intensified by the arrival and settlement of migrants from nearby villages (Picard and Moreira, 2016). These foreigners have held important positions in local organisations and active in tourism and conservation sectors. As a result, the villagers struggled to maintain their claim to political power, land and wealth. The members of the village desperately tried to engage with foreign tourism investors to create a privileged relationship yet ended up being dispossessed of the land they occupied after signing off a note allowing the foreign investors to claim the land (Picard and Moreira, 2016).

\subsection{Empowerment of the Orang Asli communities through tourism development/participation}

Empowerment is a continuous multifaceted societal transformation process, from a state of being poor and oppressed to a more position of power and control over one's wealth (Movono and Dahles, 2017). Empowerment is a transition from passivity to a more active role, taking control over one's own life, fate, and environment (Boley and McGehee, 2014). In this context, empowerment in its most fundamental sense defines the capacity of individuals, organisations, and societies to manage their affairs (Boley et al., 2017; Ramos and Prideaux, 2014).

Empowerment consists of four dimensions: economic, psychological, social and political aspects; these stress the value of control and benefit-sharing of tourism development by local communities (Movono and Dahles, 2017; Boley et al., 2017). Economic empowerment enables the community to reap the economic benefits of tourism in any particular area (Boley et al., 2017). The psychological aspect focuses on the capacity to build or reduce the pride and self-esteem of residents, perhaps making them feel inferior (Boley et al., 2017). On the other hand, social empowerment is an essential requirement for local economic development as it helps people come together to work 
towards common interests (Boley et al., 2017). Finally, the political standpoint of empowerment illustrates the importance of participation in which the whole community feels well represented, with opportunities to share their concerns about the growth of tourism (Boley et al., 2014).

Community empowerment is a catalyst to the development of community welfare through tourism, which is capable of alleviating poverty through individual-level empowerment (Knight and Cottrell, 2016; Sutawa, 2012). Community engagement in tourism activities is projected to benefit economically and socially to pursue a rewarding life (Boley et al., 2017; Sutawa, 2012). Ideally, the community empowerment mechanism transforms them into proactive individuals, able to take decisions and execute all them individually or in a group, using local resources to improve their health and wealth (Sutawa, 2012). Community empowerment increases the capacity to improve their quality of life and to educate their children (Knight and Cottrell, 2016).

\section{Methods}

Two tourism areas were selected for the study: Cameron Highlands and Bukit Tadom (Figure 1). Cameron Highlands is a district in Pahang that has long been one of the most popular mountain resorts in Malaysia, while Bukit Tadom in Selangor was developed as a tourism site only in 2015. The two communities explored are Kampung Sungai Ruil and Kampung Orang Asli Bukit Tadom, home to Orang Asli Semai and Orang Asli Temuan, respectively.

Kampung Sungai Ruil is in a prime tourism development area in Cameron Highlands. Cameron Highlands was developed as a hill resort in 1925, and the Kampung was established in 1949. The Orang Asli Semai are among the more modern of Orang Asli through their opportunity to socialise with other communities in Cameron Highlands early on, with early exposure to local and international tourists.

There are fewer written records available on the Orang Asli Temuan, even though they are the fourth largest Orang Asli group in the country, with a population of about 30,000. The settlement of Bukit Tadom is located $20 \mathrm{~km}$ from the Malaysian administrative capital Putrajaya, although it has only come to the attention of tourists since the development of a resort in 2015.

The fieldwork was conducted in February 2018 at both tourism sites (resorts) and villages. The researchers were granted access to the resorts and given permission to interview management. With help from JAKOA Malaysia, they gained access to Tok Batin (the village head) and were granted permission to enter the village for fieldwork among the villagers.

Semi-structured interviews were held, based on previous community participation studies (Xu et al., 2019; Kunjuraman and Hussin, 2017). The interviews were conducted with 14 participants, seven from each site, and included Tok Batin, villagers who were employees of the resorts, and resort management. The interviewees were selected because they were considered capable of providing rich, detailed and reliable information regarding the tourist development. The villagers were identified with the support of Tok Batin, who has comprehensive knowledge of the development of tourism in the area. The resorts' management helped to identify Orang Asli employees. 
Figure 1 Location of Bukit Tadom and Sungai Ruil (see online version for colours)

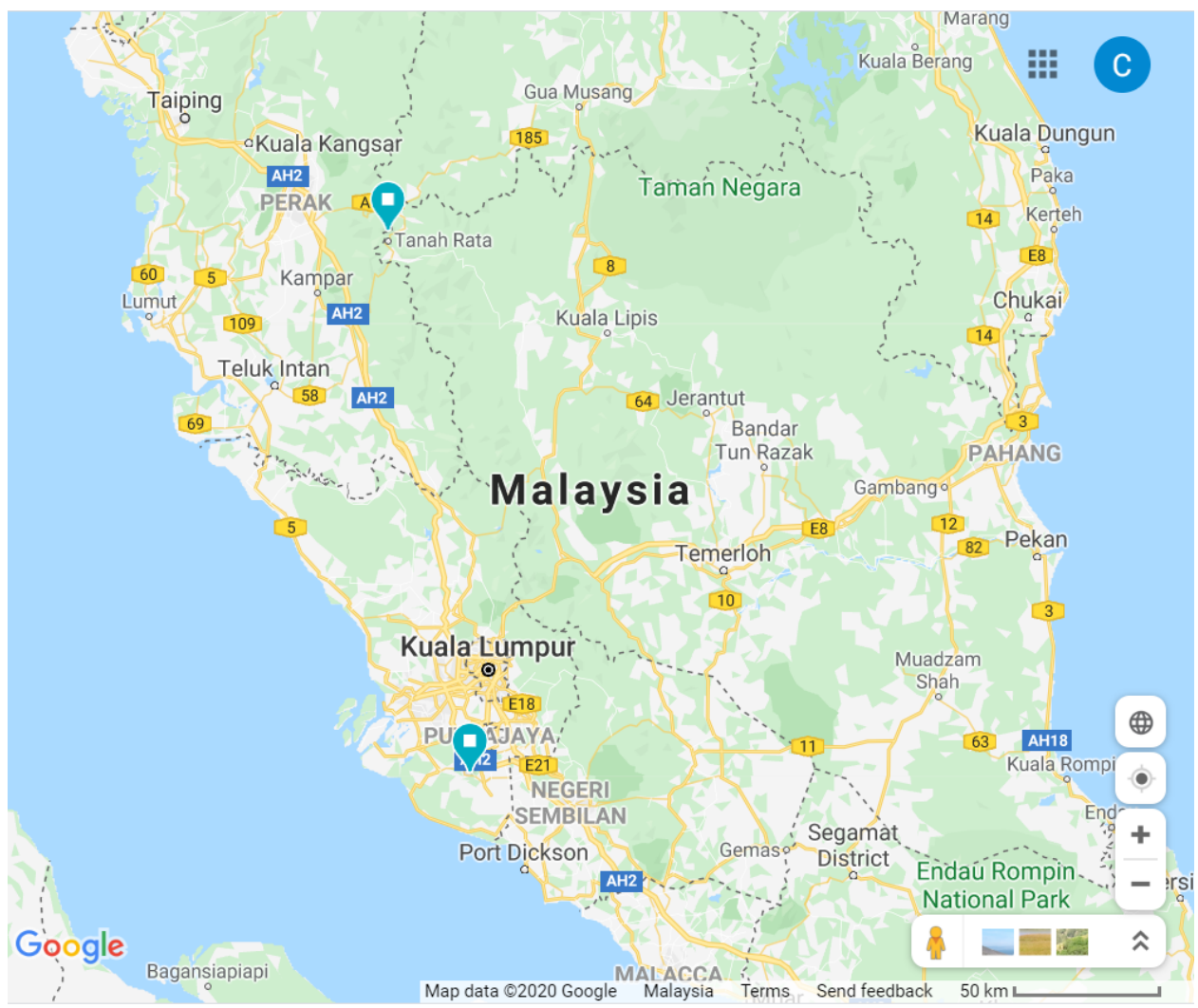

Source: Google Maps (Accessed 14 February, 2020)

The average duration of the interviews was 55 min. Interviews were conducted in Malay to suit the communication styles of the participants. Interview data were recorded, transcribed and analysed using Malay since, according to van Nes et al. (2010), translation is an interpretive act in which meaning may be lost in the translation process. However, after the analysis the results were translated into English with consideration given to the best possible way to represent the participants' understanding and experience. To ensure the reliability of the data, the transcripts were sent to the participants for confirmation. The transcript data were analysed using ATLAS.ti for coding and theme development. The final stage involved reporting and discussing the findings in relation to the research questions.

The data gained from the interviews were classified according to several themes. Each theme is discussed and supported with examples from the responses provided by the interviewees. 


\section{Results}

\subsection{Collaboration and involvement in knowledge sharing, energy and ideas to preserve nature through a partnership with NGOs and state government}

Based on the information from the interviews, Orang Asli collaboration and involvement in the tourist sites include knowledge sharing, energy and ideas to preserve nature through a partnership with NGOs and state government. The majority of participants stressed the importance of community involvement and sharing knowledge in the conservation of tourism sites. In addition, with Orang Asli collaboration and involvement, the authorities can not only preserve the site but also promote cultural and economic aspects in both areas. The following comments set out the opinions of several community members and draw attention to the role of the local community in the development of tourism sites:

Before this site was known to the tourists, Tok Batin and I had to take a look around and discuss with respected authorities where it leads to the collaboration which turn this place into a well-known tourism site. (Bukit Tadom Community, Informant 1)

With regard to contributing to improved tourism, we are here to give more ideas on how to make the resort better and more prosperous; for example, I suggested a fish pond so that the tourists can feel the biggest fish... (Bukit Tadom Community, Informant 1)

...actually what has been done by us to improve this site includes... promoting culture from our handicrafts, from history...history from our places, from lifestyles... (Bukit Tadom Community, Informant 2)

They told us, the night market is temporary... when the place is ready later, the night market will move there. (Cameron Highland Community, Informant 4)

These community members are actively involved in promoting and preserving the tourist areas. A number of Orang Asli community members now welcome and accept tourism development, even those members who were against the idea in the beginning:

...we have planned our community economy, and we village folk agree the JKK (reference to village leadership) plan gives a good income... (Cameron Highlands Community, Informant 2)

....at first ... some did not agree with concerns regarding safety, noise pollution and so on...but now, it has been three years since the resort operated here, the situations Alhamdulillah (God)...which mean...people accept it... (Bukit Tadom Community, Informant 3)

Most of the Orang Asli in the study areas are opting for a better lifestyle, as Orpia (2014) suggested. Typically, the residents choose to be involved in tourism as they believe it might bring in a good income, promote their cultural heritage and provide a better lifestyle (Orpia, 2014). The study also showed community acceptance of development as a sign of trust and networking where the community is expected to help and look for positive outcomes. Reggers et al. (2016) highlighted public engagement as increasing recognition of regional collaboration, confidence and networking, a key ingredient in providing the right conditions for successful growth of tourism.

From the interviews, Orang Asli Bukit Tadom appeared to have a clear written agreement with conditions for their land lease with the resort developer. The agreement 
stated that the resort could not construct permanent buildings which would cause environmental damage or infringe indigenous beliefs with to respect the land. Therefore, the developer built chalets from bamboo, the traditional-building material of the Orang Asli (Figure 2). This resort also offers work opportunities and free English lessons to $60 \%$ of the indigenous people who are working directly with tourists. The community has experienced a positive change along with the resort's development. This finding is supported by Mohd Ariffin and Mohd Irwan Yen (2017), that active involvement of Orang Asli in tourism development leads to a more welcoming local community and translates into positive social change.

Figure 2 Bamboo chalets in the Bukit Tadom resort (see online version for colours)

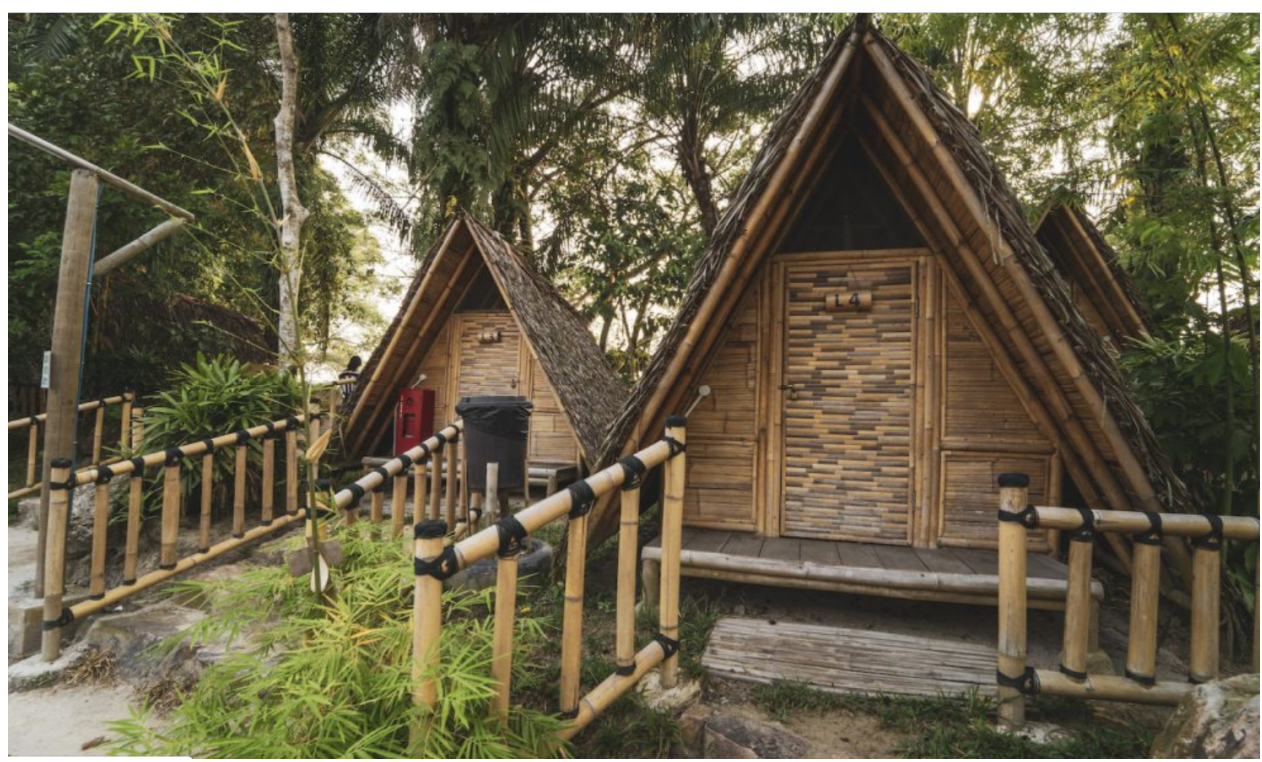

Source: Tadom Hill Resorts Website (Accessed 15 February, 2020)

However, when Cameron Highlands was developed during the British occupation of Malaya, no account was taken of the Orang Asli Sungai Ruil community. Currently, there are over 1000 hotels and resorts in Cameron Highlands, owned by Malaysian and foreign companies. Orang Asli Kampung Sungai Ruil was first perceived as a convenient local source of labour. However, this proximity was also a problem as the resort managers interviewed considered that the Orang Asli were not used to receiving instruction from others, and did not take their work seriously, many quitting their jobs after only a few months. Three Orang Asli employees agreed that they had quit at least once, but returned to work after running out of money and needing to support wife and children responsibly.

Our study also found that community involvement has contributed to the use of resources for promoting and preserving the sites. Nonetheless, Jamal and Stronza (2009) called for local communities to be active in the growth of tourism in order to bridge the gap between government and the use of resources in a tourist destination. The sense of community, as described in the literature, creates an interdependent relationship between the individual and the group. Some positively claim that the sense of community not only establishes an individual's sense of obligation and loyalty to other members of the 
community, but at the same time generates common values, beliefs and interests among individual members (Simpong et al., in press).

In line with this belief, the majority of respondents stressed that being part of the community is an important element that cannot be ignored by any individual interested in self-development in many areas. They stated that information on new opportunities, projects by government and other agencies including business, and opportunities to go further in various fields are normally channelled through the community leaders. The information received centrally is disseminated and shared by members of the community, to the benefit of individuals. This is the result of sharing knowledge with fellow community members who are actively involved in community-level efforts to stimulate a greater number of healthy businesses. In short, the ethnic communities' activities clearly override any negative aspects, creating a conducive environment of sharing general interests, developing individuals' specific interests and most importantly putting into practice their plans. The interviewees said that:

My house is provided like this...all the wood, all this wall is from us, the roof and pole from them...but others are from us; besides we are also responsible for finding all the bamboo, for the wall. (Cameron Highlands Community, Informant 3)

We promote culture, handicraft, history...history in place and lifestyle (Bukit Tadom Commnunity, Informant 2)

As a result, the collaboration and involvement of Orang Asli in terms of knowledge sharing, energy and ideas to preserve nature through partnerships with NGOs and state government indeed play a significant role, confirming attributes highlighted in past studies. This supports the claim that community participation is the creation of a democratic system and a process that allows community members to participate actively in their own growth (Levi and Litwin, 1986) as well as being willing to share and connect (Aref et al., 2010). Thus, community involvement is not to be overlooked in the development of tourism sites.

However, over-involvement by the government has caused losses to the traditions of the Orang Asli. In 2011, Kampung Sungai Ruil was affected by a landslide and damaged the settlement. The government took the initiative to grant 'better' homes for the people, by building brick houses (Figure 3 ) to replace the traditional bamboo and wooden houses. No doubt the community members were delighted to have better housing, with retaining walls, electricity and clean water. They no longer have to gather bamboo, an increasingly time-consuming process due to deforestation. However, the interviewees said that none of the original houses had been preserved, destroying the authentic aesthetics of an Orang Asli settlement which were a major tourist attraction in Cameron Highlands. The new brick houses no longer retain the identity of an Orang Asli settlement, resulting in a rapid decrease in tourists' visits.

\subsection{A more dynamic, knowledgeable and adaptive Orang Asli with respect to new development, skills and resources as a result of training and opportunity from the government}

The effect of the growth of tourism on the social aspects of the Orang Asli community in Bukit Tadom and Cameron Highlands involves creating a more diverse, knowledgeable 
and adaptive population for the new development, both skilful and resourceful as a result of government training and opportunities.

Figure 3 Brick house in Kampung Sungai Ruil (see online version for colours)

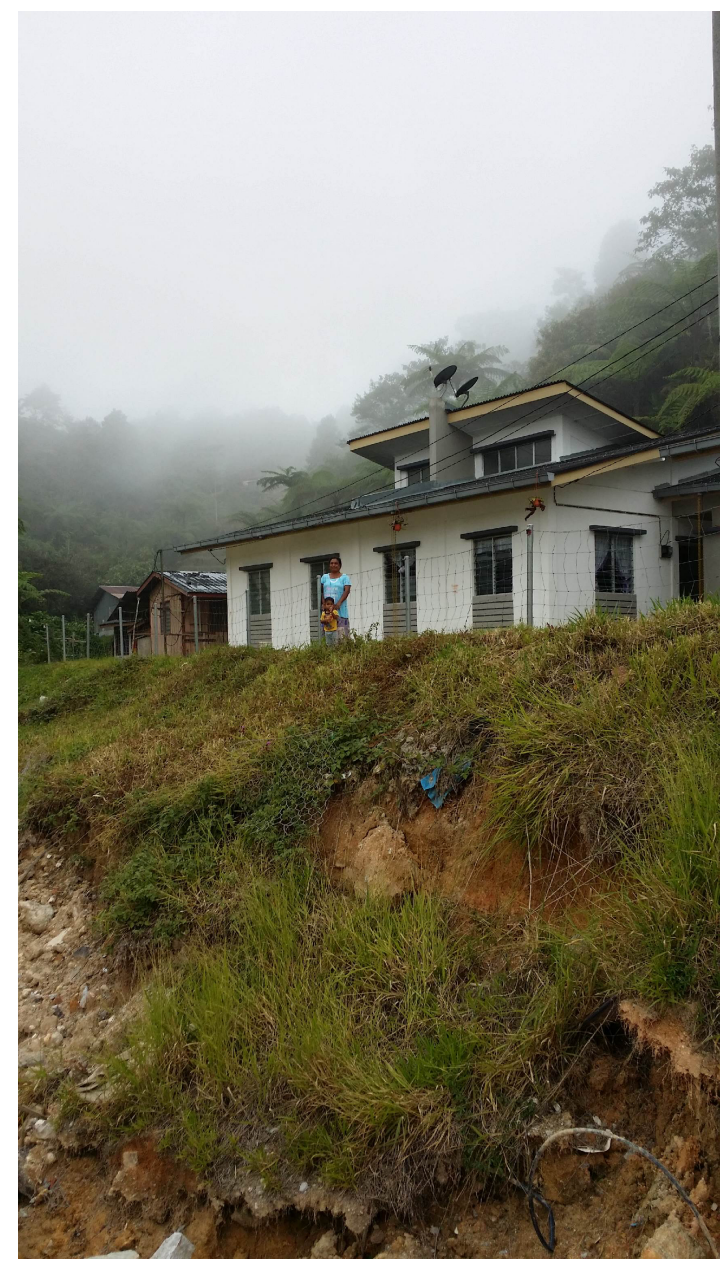

Source: Photo taken by the researcher

The Orang Asli further revealed that non-financial support is clearly seen in increased access to training opportunities in tourism education. The Ministry of Rural and Regional Development and JAKOA in collaboration with other agencies offer seminars and courses, both as explanatory sessions for beginners, and for those already familiar with travel and tourism who are seeking broader opportunities. Most of the Orang Asli stated that the training courses they attended in various centres (e.g., Damansara Damai, Sungai Buloh, Selangor, Paya Bungor, Pahang) not only increased their knowledge and improved their skills but also opened their eyes to the world beyond.

The majority of interviewees agreed that the development of these tourism sites brings positive attributes to the Orang Asli lifestyle: 
Very good compared to last time...nowadays Orang Asli adopt to situations and adapt to the environment, very good, very fast...very fast... (Bukit Tadom Management, Informant 1)

We now have cooperation in the community to take good care of our cleanliness ... (Cameron Highlands Community, Informant 1)

Hence, the study suggests that the effect of tourism development has created Orang Asli who are more dynamic, knowledgeable and adaptive towards new development, more skilful and more resourceful. Nampila (2005) said that community participation in tourism growth enhances people's sense of control over issues that affect their lives and also encourages self-confidence and self-awareness. These findings support the literature (Aref et al., 2010) which implies that the aim of community participation is to promote positive development towards community lifestyles.

\subsection{Lifestyle changes towards urbanism and modernism}

The findings also suggest that development of the selected tourism sites has created lifestyle changes towards urbanism and modernism among Orang Asli, who are sometimes regarded as belonging to other races through mixed marriage. The villagers stated that they had experienced changes in their way of life:

Now I speak like KL people [Kuala Lumpur-referring to the capital city of Malaysia]. (Bukit Tadom Community, Informant 3)

Our people before did not pay much attention to education...that is our weakness that I don't understand... (Cameron Highlands Community, Informant 2)

...sometimes there are tourists who enter the village and speak ill about us...They expected our culture to be the same as before...to be honest, last time, maybe we didn't wear clothes, now we have everything...I understand that information sometimes doesn't reached those people... when I know that the information isn't true, I will correct them...I now have income to support me and my family... (Cameron Highlands Community, Informant 7)

These responses indicate that development of the tourist sites indeed brings positive outcomes for the Orang Asli lifestyle. Although Jirojkul and Techato (2017) argued that the tourism sector has negative impacts on the local community, the results of this study suggest otherwise.

However, there is a risk of degradation of tradition. The Orang Asli of Bukit Tadom take a proactive approach by integrating their handicraft-making skills (Figure 4) as one of the paid activities at the nearby resort. This promotes their culture to the tourists and at the same time preserves their skills among young generations since these activities translate into immediate economic benefits.

On the other hand, the Orang Asli of Kampung Sungai Ruil were traditionally hunters and gatherers, knowledgeable about the forest and mountains (ilmu hutan). However, this knowledge is being lost among the young generation. One of the interviewees was promoted from the maintenance department to the travel and tours department of a resort in Cameron Highlands as he is well-versed in ilmu hutan. He takes tourists to Mossy Forest and other parts of Brinchang Mountain in Cameron Highlands. However, none of his children or nephews have inherited his knowledge, as they were sent away to boarding school. Like him, many of the parents want a better education for their children. 
Figure 4 Orang Asli Bukit Tadom explaining blowpipe construction (see online version for colours)

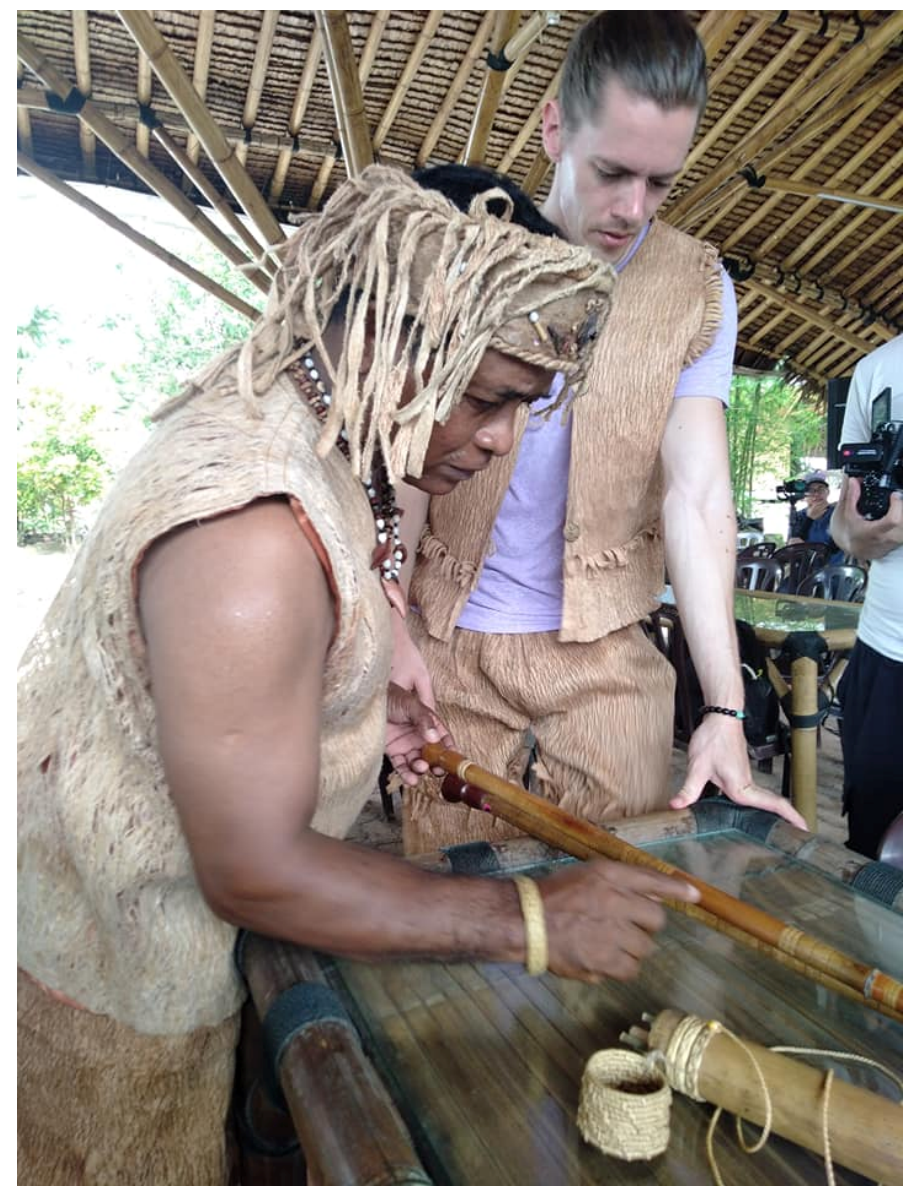

Source: Bukit Tadom Facebook page (Accessed 14 February, 2020)

The results of the study indicate that the development of the tourist site has positive results for the Orang Asli's lifestyle, consistent with the literature, which indicates the positive impact of the growth of tourism on the quality of life of the local community (Uysal et al., 2016; Simpong et al., in press).

Furthermore, based on the findings, the Orang Asli are more flexible towards modernisation and urbanisation, especially among the younger generation. During the interviews, the majority of participants indicated acceptance of the development and tourist arrivals in their community and the surrounding areas.

If for me, I think us (the community) are okay, plus they (tourist) came just for relaxing their mind. (Cameron Highlands Community, Informant 1)

Even with modernisation, culture is still there... (Cameron Highlands Community, Informant 3)

The findings indicate that the development of tourism contributes to the positive improvement of the Orang Asli lifestyle, supporting an earlier study (Lee and Jan, 2019). 


\subsection{Improving economic status and household income of the orang asli community through job opportunities and a priority status for them}

The majority of interviewees believe that the growth of the Orang Asli tourism site has improved their economic status and household incomes:

What is positive for me is, the landlord will get the benefit from the land which used to support household... (Bukit Tadom Community, Informant 1)

Yes...in terms of job opportunities no problem... (Cameron Highlands Employee, Informant 3)

Staff here... $80 \%$ is Orang Asli, $20 \%$ outsider, meaning that priority is given to Orang Asli... (Cameron Highlands Management, Informant 1)

Yes..there is a change.....as far as we know before this...majority of the staff here were working as palm plantation workers...where their incomes are based on the factory profit...which means if loss of profit their income will be less and opposite compared to here (referring to working in the resort)... (Bukit Tadom Management, Informant 2)

The positive attitudes towards the Orang Asli's economic development support the findings of several authors (Harron and Weiler, 1992; Mohd Ariffin and Mohd Irwan Yen, 2017; Ridzuan et al., 2018) who emphasise the economic impact of tourism growth, such as increased job opportunities, higher incomes and improved living conditions for the community. However, equal opportunity in economic activities is still below other communities in the area. One interviewee said:

...we are not doing business...there is no chance for us...the majority of the night market sellers are Chinese and Indian...they owned plantations, their own gardens... the majority of villagers are employed in private and government sectors... none of us are doing business... (Cameron Highlands community, Informant 7)

The findings are also consistent with a past study claiming that tourism development has positive impacts, including improvement in local economic conditions, social and cultural understanding and protection of environmental resources (Mihalic, 2016; Yolal et al., 2016). Hence, the needs of local communities in the tourism growth process must be carefully considered.

Therefore, based on our findings, tourism development has resulted in positive outcomes for the Orang Asli communities in the sites selected for the study. The results also support an earlier study; according to Idziak et al. (2015), community participation can turn the passive attitude of the public into a proactive and constructive outlook, encouraging entrepreneurial ventures, building partnerships and cooperation, cultivating a spirit of unity and rejuvenating relationships between citizens, tourism destinations and external stakeholders; thus, such participation will increase the potential for more effective participation.

\section{Conclusion}

The tourism industry can have positive and negative effects on the local community as it can affect the lives of members in a number of ways. Tourism may profit some local 
communities through the overall growth of the area, but it may have a negative effect on other communities.

Orang Asli Bukit Tadom are more conscious of the value of their land. They were isolated from nearby communities before the development of the resort. They also learned from previous the land ownership problems of the other Orang Asli communities, and negotiated with resort developers to ensure economic sustainability and job opportunities for the community. They have integrated Temuan culture into the resort activities. However, there is still much to explore in the extent of authentic Orang Asli traditions in tourism.

Community participation is therefore essential in order to improve the quality of tourism's contribution to national development. Indeed, providing deeper consideration and understanding of suitable ways to encourage local involvement is crucial to a positive impact in tourism site development. Therefore, government and local authorities are advised to take the initiative to create more advanced collaboration with the community in every tourism site development program. This will allow for a more comprehensive understanding of the circumstances of the tourist site, based on community expectations. Orang Asli communities presented in this study want to be proactively involved in tourism development. However, there is lack of platform for tourism planning and development discussion between government and developer with Orang Asli communities. A more engaging communication channels will help the government and local authorities developing the tourist sites to its full potential and improving community lifestyles and the societal economy in the process.

This study has contributed towards the development of new perspectives in tourism development among indigenous peoples, specifically in developing countries, which indirectly opens new opportunities to study the effects of tourism development on the selected sites from a long-term perspective. Meanwhile, the authorities benefit in designing new strategies for future developments based on the findings of this report. The study proposes new standpoints in terms of planning and policy perspectives by suggesting considerations in regards to community acceptance, involvement and demand for benefits. Therefore, supports sustainable development goals no. 10, to help reduce inequalities within and among countries by providing Orang Asli with a capacity for participation in tourism development, as well as fair and equitable distribution of benefits.

There are still much to be known of the extent of Orang Asli participation in tourism, such as their readiness for tourism development. As Orang Asli still own and occupy many unexplored areas in Malaysia, and there is constant interest in commercial tourism development, more in-depth study is needed in terms of land ownership, profit sharing and the extent of involvement in tourism development projects in other Orang Asli community.

\section{Acknowledgements}

This work was supported by the Ministry of Higher Education (MOHE) Malaysia under Fundamental Research Grant Scheme FRGS/1/2017/SS06/UMK/03/1. 


\section{References}

Alshboul, K. (2016) Assessing Local Community Involvement in Tourism Development Around a Proposed World Heritage Site in Jerash, Jordan, Doctoral dissertation, University of Waterloo.

Amoamo, M. and Thompson, A. (2010) '(re)Imaging Māori tourism: representation and cultural hybridity in postcolonial New Zealand', Tourist Studies, Vol. 10, pp.35-55.

Aref, F., Ma'rof, R. and Sarjit, S.G. (2010) 'Dimensions of community capacity building: a review of its implications in tourism development', Journal of American Science, Vol. 6, pp.172-180.

Boley, B.B. and Mcgehee, N.G. (2014) 'Measuring empowerment: developing and validating the resident empowerment through tourism scale (RETS)', Tourism Management, Vol. 45, pp.85-94.

Boley, B.B., Ayscue, E., Maruyama, N. and Woosnam, K.M. (2017) 'Gender and empowerment: assessing discrepancies using the resident empowerment through tourism scale', Journal of Sustainable Tourism, Vol. 25, pp.113-129.

Boley, B.B., Mcgehee, N.G., Perdue, R.R. and Long, P. (2014) 'Empowerment and resident attitudes toward tourism: strengthening the theoretical foundation through a weberian lens', Annals of Tourism Research, Vol. 49, pp.33-50.

Bookbinder, M.P., Dinerstein, E., Rijal, A., Cauley, H. and Rajouria, A. (1998) 'Ecotourism's support of biodiversity conservation', Conservation Biology, Vol. 12, pp.1399-1404.

Bordas Rubies, E. (2001) 'Improving public-private sectors cooperation in tourism: a new paradigm for destinations', Tourism Review, Vol. 56, pp.38-41.

Bramwell, B. (2011) 'Governance, the state and sustainable tourism: a political economy approach', Journal of Sustainable Tourism, Vol. 19, pp.459-477.

Campón-Cerro, A.M., Folgado-Fernández, J.A. and Hernández-Mogollón, J.M. (2017) 'Rural destination development based on olive oil tourism: the impact of residents' community attachment and quality of life on their support for tourism development', Sustainability, Vol. 9, p.1624.

Cardow, A. and Wiltshier, P. (2010) 'Indigenous tourism operators: the vanguard of economic recovery in the Chatham islands', International Journal of Entrepreneurship and Small Business, Vol. 10, pp.484-498.

Carr, A., Ruhanen, L. and Whitford, M. (2016) 'Indigenous peoples and tourism: the challenges and opportunities for sustainable tourism', Journal of Sustainable Tourism, Vol. 24, pp.1067-1079.

Chang, K.G., Sullivan, W.C., Lin, Y.H., Su, W. and Chang, C.Y. (2016) 'The effect of biodiversity on green space users' wellbeing-An empirical investigation using physiological evidence', Sustainability, Vol. 8, p.1049.

Chang, K., Chien, H., Cheng, H. and Chen, H-I. (2018) 'The impacts of tourism development in rural indigenous destinations: an investigation of the local residents' perception using choice modeling', Sustainability, Vol. 10, p.4766.

Curcija, M., Breakey, N. and Driml, S. (2019) 'Development of a conflict management model as a tool for improved project outcomes in community based tourism', Tourism Management, Vol. 70, pp.341-354.

Dola, K. and Mijan, D. (2006) 'Public participation in planning for sustainable development: operational questions and issues', International Journal on Sustainable Tropical Design Research and Practice, Vol. 1, pp.1-8.

Duffy, R. (2000) 'Shadow players: ecotourism development, corruption and state politics in Belize', Third World Quarterly, Vol. 21, pp.549-565.

Eshliki, S.A. and Kaboudi, M. (2012) 'Community perception of tourism impacts and their participation in tourism planning: a case study of Ramsar, Iran', Procedia-Social Behavioral Sciences, Vol. 36, pp.333-341. 
Fletcher, C., Pforr, C. and Brueckner, M. (2016) 'Factors influencing indigenous engagement in tourism development: an international perspective', Journal of Sustainable Tourism, Vol. 24, pp.1100-1120.

Ghazali, S., Chan, N.W. and Nor, N.M. (2006) 'The economic and socio-cultural impacts of ecotourism on the Orang Asli in Cameron highlands, Pahang, Malaysia', in Chan, N.W. (Ed.): BTFC: Issues and Challenges in Sustainable Development, Universiti Sains Malaysia, Penang.

Griffin, T. (2002) ‘An optimistic perspective on tourism's sustainability', in Harris, R.G., Tony and Williams, P. (Eds.): Sustainable Tourism: A Global Perspective, Routledge, London.

Harron, S. and Weiler, B. (1992) 'Ethnic tourism', in Weiler, B. and Hall, C.M. (Eds.): Special Interest Tourism, Belhaven Press, London.

He, G., Chen, X., Liu, W., Bearer, S., Zhou, S., Cheng, L.Y., Zhang, H., Ouyang, Z. and Liu, J. (2008) 'Distribution of economic benefits from ecotourism: a case study of Wolong Nature Reserve for giant pandas in China', Environmental Management, Vol. 42, p.1017.

Idziak, W., Majewski, J. and Zmyślony, P. (2015) 'Community participation in sustainable rural tourism experience creation: a long-term appraisal and lessons from a thematic villages project in Poland', Journal of Sustainable Tourism, Vol. 23, pp.1341-1362.

Jaafar, M., Rasoolimanesh, S.M. and Ismail, S. (2017) 'Perceived sociocultural impacts of tourism and community participation: a case study of Langkawi Island', Tourism and Hospitality Research, Vol. 17, pp.123-134.

Jamal, T. and Stronza, A. (2009) 'Collaboration theory and tourism practice in protected areas: stakeholders, structuring and sustainability', Journal of Sustainable Tourism, Vol. 17, pp.169-189.

Jirojkul, S. and Techato, K. (2017) 'Social responsibility in community-based tourism enterprise', Journal of Engineering and Applied Sciences, Vol. 12, pp.1825-1829.

Kamaruddin, K. and Jusoh, O. (2008) 'Educational policy and opportunities of Orang Asli: a study on indigenous people in Malaysia', Journal of Human Resource and Adult Learning, Vol. 4, pp.86-97.

Knight, D.W. and Cottrell, S.P. (2016) 'Evaluating tourism-linked empowerment in Cuzco, Peru', Annals of Tourism Research, Vol. 56, pp.32-47.

Kunjuraman, V. and Hussin, R. (2017) 'Challenges of community-based homestay programme in Sabah, Malaysia: hopeful or hopeless?', Tourism Management Perspectives, Vol. 21, pp.1-9.

Lapeyre, R. (2010) 'Community-based tourism as a sustainable solution to maximise impacts locally? the Tsiseb conservancy case, Namibia', Development Southern Africa, Vol. 27, pp.757-772.

Latip, N.A., Rasoolimanesh, S.M., Jaafar, M., Marzuki, A. and Umar, M.U. (2018) 'Indigenous participation in conservation and tourism development: a case of native people of Sabah, Malaysia', International Journal of Tourism Research, Vol. 20, pp.400-409.

Lee, T.H. and Jan, F-H. (2019) 'Can community-based tourism contribute to sustainable development? evidence from residents' perceptions of the sustainability', Tourism Management, Vol. 70, pp.368-380.

Lemelin, R.H., Thompson-Carr, A., Johnston, M., Stewart, E. and Dawson, J. (2013) 'Indigenous people: discussing the forgotten dimension of dark tourism and battlefield tourism', in Müller, D.K., Linda, L., and Lemelin, R.H. (Eds.): New Issues in Polar Tourism, Springer, Dordrecht.

Lepper, C.M. and Schroenn Goebel, J. (2010) 'Community-based natural resource management, poverty alleviation and livelihood diversification: a case study from northern Botswana', Development Southern Africa, Vol. 27, pp.725-739.

Levi, Y. and Litwin, H. (1986) Community and Cooperatives in Participatory Development, Aldershot, Gower.

Lim, H.F., Woon, W.C.M. and Mohd Parid (2006) 'The Orang Asli and ecotourism development in in BTFC', in Chan, N.W. (Ed.): BTFC: Issues and Challenges in Sustainable Development, Universiti Sains Malaysia, Penang. 
Matthews, E.J. (2002) Ecotourism: Are Current Practices Delivering Desired Outcomes? A Comparative Case Study Analysis, Masters in Urban and Regional Planning Masters Thesis, Virginia Polytechnic Institute and State University.

Mbaiwa, J.E. and Stronza, A.L. (2010) 'The effects of tourism development on rural livelihoods in the Okavango delta, Botswana', Journal of Sustainable Tourism, Vol. 18, pp.635-656.

Mihalic, T. (2016) 'Sustainable-responsible tourism discourse - towards', 'responsustable' tourism', Journal of Cleaner Production, Vol. 111, pp.461-470.

Mohd Ariffin, A.R. and Mohd Irwan Yen, A. (2017) 'Sustainable agrotourism curating by conferring community involvement in Tanah Rata, Cameron Highlands, Malaysia', Journal of Design and Built Environment, Special Issue, pp.38-52.

Monovo, A. and Dahles, H. (2017) 'Female empowerment and tourism: a focus on businesses in a Fijian village', Asia Pacific Journal of Tourism Research, Vol. 22, pp.681-692.

Mtapuri, O. and Giampiccoli, A. (2017) 'A conceptual coalescence: towards luxury community based tourism', African Journal of Hospitality, Tourism and Leisure, Vol. 6, pp.1-14.

Muresan, I.C., Oroian, C.F., Harun, R., Arion, F.H., Porutiu, A., Chiciudean, G.O., Todea, A. and Lile, R. (2016) 'Local residents' attitude toward sustainable rural tourism development. Sustainability, Vol. 8, 100.

Nampila, T. (2005) Assessing Community Participation: The Huidare Informal Settlement, MPhil Masters thesis, University of Stellenbosch.

Nunkoo, R. and Gursoy, D. (2012) 'Residents' support for tourism: an identity perspective', Annals of Tourism Research, Vol. 39, pp.243-268.

Orpia, C.B. (2014) 'Analysis of the involvement and impressions of the local community on the tourism development of Ilocos Norte', SHS Web of Conferences, 2014 Kota Kinabalu, EDP Sciences, p.01049.

Peters, M., Chan, C-S. and Legerer, A. (2018) 'Local perception of impact-attitudes-actions towards tourism development in the Urlaubsregion Murtal in Austria', Sustainability, Vol. 10, No. 2360).

Picard, D. and Moreira, C.N. (2016) 'Colonial memory, hospitality and tourism in southwestern Madagascar', Int. J. Tourism Anthropology, Vol. 5, pp.187-203.

Ramos, A.M. and Prideaux, B. (2014) 'Indigenous ecotourism in the Mayan rainforest of Palenque: empowerment issues in sustainable development', Journal of Sustainable Tourism, Vol. 22, pp.461-479.

Rasoolimanesh, S.M. and Jaafar, M. (2016) 'Residents' perception toward tourism development: a pre-development perspective', Journal of Place Management and Development, Vol. 9, pp.91-104.

Rasoolimanesh, S.M., Jaafar, M. and Tangit, T.M. (2018) 'Community involvement in rural tourism: a case of Kinabalu National Park, Malaysia', Anatolia, Vol. 29, pp.337-350.

Reggers, A., Grabowski, S., Wearing, S.L., Chatterton, P. and Schweinsberg, S. (2016) 'Exploring outcomes of community-based tourism on the Kokoda Track, Papua New Guinea: a longitudinal study of participatory rural appraisal techniques', Journal of Sustainable Tourism, Vol. 24, pp.1139-1155.

Ridzuan, N.A., Ibrahim, M., Razali, N.A.M., Samengon, H. and Rusli, S.A. (2018) Impact of rural tourism products development on tourist spending in poverty alleviation: a case study of Tadom Hill', Journal of Tourism, Hospitality and Environmental Management, Vol. 3, pp.23-28.

Saarinen, J. and Lenao, M. (2014) 'Integrating tourism to rural development and planning in the developing world', Development Southern Africa, Vol. 31, pp.363-372.

Salleh, N.H.M., Othman, R., Idris, S.H.M., Jaafar, A.H. and Selvaratnam, D. (2013) 'The effects of tourism development towards livelihood sustainability of the Orang Asli at the Kg. Sg. Ruil, Cameron Highlands', Tourismos, Vol. 8, pp.301-321. 
Simpong, D.B., Zahari, M.S.M., Hanafiah, M.H. and Ahmad, R. (in press) 'Indigenous peoples, and tourism business opportunity: the influence of Orang Aslis personality traits and sense of community', International Journal of Tourism Anthropology.

Simpong, D., Zahari, M.S.M., Akbarruddin, M.N.A. and Hadi, H.A. (2016) 'Indigenous entrepreneurs and the moderating effect of social capital and government support on mainstream business intention', in Radzi, S.M., Hanafiah, M.H.M., Sumarjan, N., Mohi, Z., Sukyadi, D., Suryadi, K. and Purnawarman, P. (Eds.): Heritage, Culture and Society: Research Agenda and Best Practices in the Hospitality and Tourism Industry, CRC Press/Balkema, Leiden.

Sofield, T. and Li, F.M.S. (2007) 'China: Ecotourism and cultural tourism, harmony or dissonance', in Higham, J. (Eds.): Critical Issues in Ecotourism: Understanding a Complex Tourism Phenomenon, Butterworth-Heinnemann, Oxford.

Stronza, A. and Gordillo, J. (2008) 'Community views of ecotourism', Annals of Tourism Research, Vol. 35, pp.448-468.

Sutawa, G.K. (2012) 'Issues on Bali tourism development and community empowerment to support sustainable tourism development', Procedia Economics and Finance, Vol. 4, pp.413-422.

Thetsane, R.M. (2019) 'Local community participation in tourism development: the case Katse Villages in Lesotho', Athens Journal of Tourism, Vol. 6, pp.123-140.

Thompson-Carr, A. (2013) 'A case study of managing indigenous cultural values', in Smith, M. and Richards, G. (Eds.): The Routledge Handbook of Cultural Tourism, Routledge.

Tonnaer, A. (2016) 'Intersecting journeys of past and present in the', 'bush': unsettling coevalness in the tourist space of indigenous Australia', International Journal of Tourism Anthropology, Vol. 5, pp.172-186.

Uysal, M., Sirgy, M.J., Woo, E. and Kim, H. (2016) 'Quality of life (QOL) and well-being research in tourism', Tourism Management, Vol. 53, pp.244-26a1.

van Nes, F., Abma, T., Jonsson, H. and Deeg, D. (2010) 'Language differences in qualitative research: is meaning lost in translation?', European Journal of Ageing, Vol. 7, pp.313-316.

Weaver, D. (2010) 'Indigenous tourism stages and their implications for sustainability', Journal of Sustainable Tourism, Vol. 18, pp.43-60.

Whitford, M. and Ruhanen, L. (2016) 'Indigenous tourism research, past and present: where to from here?', Journal of Sustainable Tourism, Vol. 24, pp.1080-1099.

Xu, H., Jiang, F., Wall, G. and Wang, Y. (2019) 'The evolving path of community participation in tourism in China', Journal of Sustainable Tourism, Vol. 27, pp.1239-1258.

Xue, L., Kerstetter, D. and Hunt, C. (2017) 'Tourism development and changing rural identity in China', Annals of Tourism Research, Vol. 66, pp.170-182.

Yolal, M., Gursoy, D., Uysal, M., Kim, H. and Karacaoğlu, S. (2016) 'Impacts of festivals and events on residents' well-being. Annals of Tourism Research, Vol. 61, pp.1-18.

Yu, C-Y. (2018) 'An application of sustainable development in indigenous people's revival: The history of an indigenous tribe's struggle in Taiwan', Sustainability, Vol. 10, p.3259.

Zamil, A. (2011) 'The role of Jordanian local community in marketing tourism', Journal of Business Studies Quarterly, Vol. 2, pp.42-49.

Zeppel, H. (2006) Indigenous Ecotourism: Sustainable Development and Management, Oxfordshire, CABI. 